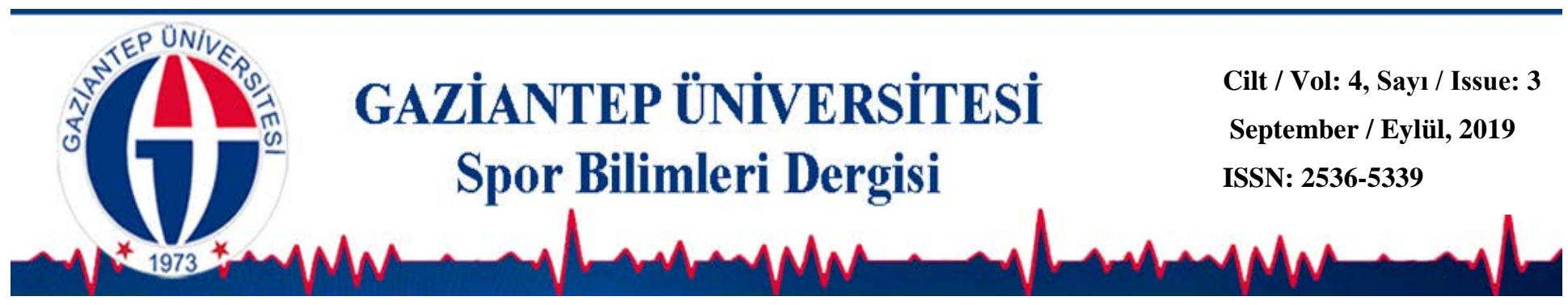

\title{
Çocuklarda Sosyo-Ekonomik Düzeyin Fiziksel ve Fizyolojik Performanslarıyla Ílişkisi
}

\author{
Dursun GÜLER ${ }^{1 *}$ (D) \\ ${ }^{1}$ Amasya Üniversitesi, Eğitim Fakültesi, Beden Eğitimi ve Spor Bölümü, AMASYA
}

DOI: 10.31680/gaunjss.542510

Orijinal Makale / Original Article

Geliş Tarihi / Received: 20.03.2019

Kabul Tarihi / Accepted: 15.08.2019

Yayın Tarihi / Published: 22.09.2019

\section{Öz}

Araştırmanın amacı, çocuklarda sosyo-ekonomik düzeyin sporcu performansı ile olan iliş̧isinin belirlenmesi ve değerlendirilmesiydi. Çalışmaya, Burdur'daki ortaokullarda okuyan ve okullar arası futbol müsabakalarında futbol oynayan 109 gönüllü sağlıklı erkek öğrenci katıldı. Dataların analizinde, tüm parametrelere yönelik ortalama, standart sapma, maksimum ve minimum değerleri alındı. Çalışmaya katılan tüm öğrencilerin sosyoekonomik düzeyleri ile fiziksel, fizyolojik ve teknik özellikleri arasında ilişsi olup olmadığı Korelasyon Analizi (Pearson) testi ile belirlendi. Değerlendirme sonucunda, anne eğitim düzeyi ile barfikste kol çekme $(P<0,01)$ ve dikey sıçrama $(P<0,05)$ arasında ve baba eğitim düzeyi ile kilo, VKi, yağ yüzdesi, esneklik, barfikste kol çekme ve dikey sıçrama arasında $(P<0,05)$ anlamlı doğrusal ilişki; baba eğitim düzeyi ile ektomorfik yapı arasında anlamlı $(P<0,05)$ ters iliş̧i görüldü. Anne ve baba eğitim düzeyi arttıkça anaerobik güç de anlamlı $(P<0,01)$ şekilde arttı. Çocukların yaşadıkları çevre modernleştikçe $10 \mathrm{~m}$ koşu $(P<0,05)$ ve $30 \mathrm{~m}$ koşu $(P<0,01)$ performansları anlamlı pozitif ilişki gösterdi. Çocuklar kendilerine ait odaya sahip oldukça vücut yoğunluklarında anlamlı $(P<0,05)$ artış gözlenirken, esneklikleri ve endomorfik yapılarında anlamlı $(P<0,05)$ düşüş gözlendi. Diğer değişkenler ile performans kriterleri arasında istatistiki bakımdan anlamı $(P>0,01, P>0,05)$ bir ilişki bulunmadı. Sonuç olarak, sürekli aktif olan çocuklarda, anne-baba eğitimi ve yaşam çevrelerinin kuvvet, yağ düzeyleri, hareketlilik ve anaerobik güçlerine etkileri olabilmektedir.

Anahtar Kelimeler: Çocuklar, sosyo-ekonomik durum, fiziksel performans, fizyolojik performans, sportif performans.

\section{The Relationship With Athlete Performance of the Socio-Economic Level in Children}

\begin{abstract}
The aim of this study, is determined of the relationship with athlete performance of the socio-economic level in children. Total 109 students who were male football players in the teams that took place in football championships at secondary schools in Burdur. At the statistical analyses of the datas were obtained the mean, standard deviation, maximum and minimum values for all parameters and Correlation Analyses (Pearson) tests were used for the evaluation of the relationship between the physical, physilogic and technic characteristics with socioeconomic level of the participants. At result of estimate; it was observed significant relationship between strength in pull-up $(P<0,01)$ and vertical jump $(P<0,05)$ with education of children's mather. It was observed significant relationship between body weight, BMI (Body Mass Index), fat percentage, flexibility, strength in pull up and vertical jump $(P<0,05)$ with education of children's father and, significant negative relationship between ectomorphic structure $(P<0,05)$ with education of children's father. It increased as significant $(P<0,01)$ children's anaerobic power when education levels of children's father and mather are increasing. It increased as significant children's $10 \mathrm{~m}$ run $(P<0,05)$ and $30 \mathrm{~m}$ run $(P<0,01)$ performances when children's living environments are modernizing. It was found that significant relationship between children's body density $(P<0,05)$, negative significant relationship $(P<0,05)$ between children's flexibility and endomophic structure that children have to one's room in their home. It was observed non significant relationship $(P>0,05, P>0,01)$ among other variables. As a result, it was able to effect their strenghts, fat levels, flexibilities and anaerobic powers of educations of children's father and mather and living environments at constantly active children.
\end{abstract}

Keywords: Children, socio-economic state, physical performance, physiologic performance, sportive performance.

\footnotetext{
* Sorumlu Yazar: Dursun GÜLER

E-mail: dursun.guler@amasya.edu.tr ${ }^{*} \mathrm{Bu}$ çalışmanın bir kısım verileri Mehmet Akif Ersoy Üniversitesi Bilimsel Araştırma Projeleri Komisyonu tarafından desteklenen 017-NAP-07 no'lu projeden alınmıştır.
} 


\section{Giriş}

Bireyler, toplumsal yaşamlarında, sosyal yapılarını oluşturan sosyo-ekonomik kriterler çerçevesinde sosyal statülerini belirlemekte ve yaşam süreçlerine yön verebilmektedirler. Dolayısıyla, sosyo-ekonomik olarak yüksek düzey ve refah içerisinde bulunan kişiler, içerisinde bulunduğu toplumun çoğundan daha üst düzeyde bir yaşam ölçülerine sahiptirler (Kuru ve Pepe, 2002).

Anne ve baba eğitimi, çocukların yaşadığı çevre, beslenme ve ebeveyn bakış açıları gibi sosyo-ekonomik ve sosyo-kültürel yapı, çocuklarda spora yönelimi ciddi şekilde etkilemekte ve spor faaliyetlerinin seçiminde belirleyici rol oynamaktadır. Spor, ailelerin sosyo-ekonomik düzey ve sosyo-kültürel yapılarına bağlı şekilde yayılmakta ve zenginleşmektedir (Bayraktar, 2011).

Çocuklar, büyüme ve sinir sistemi olgunlaşmasına bağlı normal gelişim gösterirken, aynı zamanda hareket becerilerini de kazanırlar. Motor becerilerini kazanmaları bazı parametrelerin etkisi altında olup; cinsiyet, beslenme, kültür ve gelenekler, kalıtım, ırk, vücut ölçülerinin olgunlaşma hızı, sosyo-ekonomik yapı, hormonal düzey (hipofiz, tiroid hormonları gibi), ailenin çocuk yetiştirme becerileri gibi faktörler hareket ve beceri gelişimini etkilemektedir (Akgün, 1997).

Performans, fiziksel aktiviteler esnasında, o fiziksel aktivitelerin gereği olan fiziksel, fizyolojik, biyomekanik ve psikolojik verimlilik olarak ifade edilmektedir (Astrand ve Rodahl 1986). Performansı olumlu ve olumsuz etkileyen faktörler vardır. Bu faktörler oluşum kaynaklarına göre içsel ve dışsal faktörler olarak ikiye ayrılırlar. İçsel faktörlere göre dışsal faktörlerin sayısı daha fazladır. Kalıtım, aile, sosyal çevre, ekonomik bileşenler ve beslenme performansı etkileyen faktörlerden bazılarıdır. Sportif verimliliği geliştirmek amacı ile performans bileşenlerini kullanmak, gereken düzenlemeler yapmak daha basit ve etkili görünmektedir (Bayraktar ve Kurtoğlu, 2011).

Performansı etkileyen tüm faktörler göz önünde bulundurularak bir çok uygulamayla performansın optimum düzeyde artırılması amaçlanmıştır. Bilimsel disiplinler çerçevesinde etkin motivasyona ilişkin iç-dış uyaranlar, yeterli beslenme, ekonomik yetkinlik, düzenli uyku, uygun dinlenme, uygun ve etkin rekreatif etkinlikler, olumlu ev koşulları, güzel alışkanlıklar, ergonomik antrenman malzemeleri, uygun iklim şartları, verimli ısınma, yeterli esneklik düzeyi, mental ve fiziksel antrenman 
Güler D., (2019). Çocuklarda Sosyo-Ekonomik Düzeyin Fiziksel ve Fizyolojik Performanslarıyla İlişkisi. Gaziantep Üniversitesi Spor Bilimleri Dergisi, 4(3), 275-288.

planları, spesifik teknik ve taktik aktiviteler sportif performansı, yani başarıyı maksimal düzeyde artıracaktır (Bayraktar ve Kurtoğlu 2009).

Sporun kitlelere yayılması, çocukların sağlıklı gelişimlerine ilişkin etkenler içerisinde fiziksel aktivite ve hareket performanslarının öneminin vurgulanması ve de farkındalık oluşturulması, daha küçük yaşlarda çocukların beceri performanslarının altında yatan gerçeklerin belirlenmesi gibi değişkenlerin tespit edilmesi önemli olduğundan, bu çalışmada, aktif olarak spor yapan çocukların, sosyo-ekonomik düzeylerinin sportif performans ile ilişkisinin belirlenmesi ve değerlendirilmesi amaçlanmıştır.

\section{Yöntem}

\section{Araştırma Grubu}

Çalışmaya; yarışmalarda başarılı performans ile sosyoekonomik bileşenler arasındaki ilişkiye vurgu yapılması açısından, yalnızca, Burdur'da ortaokullar arası futbol yarışmalarında ilk üç derecedeki takımlardan 36 , elenmiş veya dereceye girememiş takımlardan 39 ve spor faaliyetlerinde bulunmayan 34 olmak üzere toplam olarak 109 gönüllü, sağlıklı erkek öğrenci katıldı.

\section{Verilerin Toplanması}

Araştırmada kullanılan tüm bulgular, aşağıda belirtilen ölçüm yöntemi ve testler kullanılarak elde edildi:

- Sosyo-ekonomik yapı: Sosyo-ekonomik yapının belirlenmesi için tüm çocuklara Öğrenci Kişisel Bilgi Formu verilerek doldurmaları istendi.

- Boy uzunluğu ve vücut ağırlığı ölçümü: Sporcu çocukların boy uzunluğu ve vücut ağırlıkları ölçüldü; vücut yağ düzeylerinin değerlendirilmesinde kullanılmak üzere Vücut Kitle İndeksleri (VKI) belirlendi.

- Vücut kompozisyonu ölçümü ve somatotip özellikler: Vücut yağ yüzdesi Lohman (1994)' ın formülü (Short ve Winnick 2005; IOC, 1996); somatotip özellikler de Heat-Carter somatotip belirleme ve derecelendirme yöntemi (Carter ve Heath 1990; Macdougall ve ark., 1983) ile tespit edildi.

- Esneklik testi: Çocukların esneklik düzeyleri otur-eriş testiyle belirlendi ve test, otur-eriş sehpası ile gerçekleştirildi.

- Kas kuvveti ve dayanıklılığı testleri: Kuvvet ve kuvvette devamlılık testleri 1 dk'lık bükülü bacak mekik çekme ve yaklaşık 2,5 cm. çapındaki bir barda yorulana kadar 
barfikste kol çekme testi uygulandı. Dikey sıçrama testi de yapıldı ve anaerobik gücün belirlenmesi Lewis formülü ile yapıldı.

- Sürat testi: Sürat ölçümünde $10 \mathrm{~m}$ ve $30 \mathrm{~m}$ sürat testi kullanıldı.

- Teknik test: Top sürme ve bant üzerinden gol atma testi uygulandı (Şekil 1). Bu testle sporcuların toplu ve topsuz sürat ve isabetli şut atabilme düzeylerinin belirlenmesi amaçlandı (Özkara, 2004).

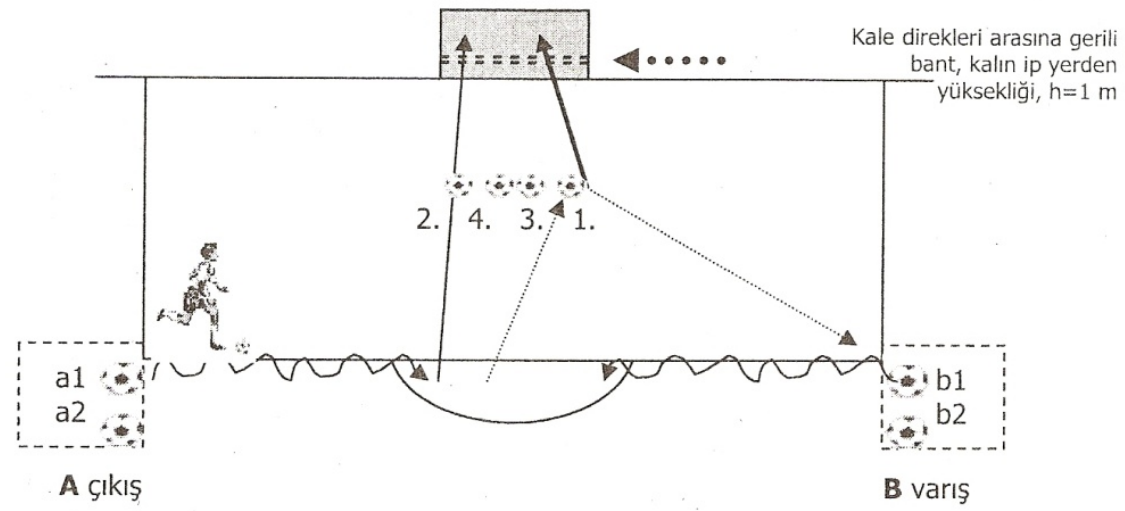

Şekil 1. Top ile Koşudan Sonra İsabetli Şut Atma Testi Düzeneği (Özkara, 2004).

- Aerobik Dayanıklılık Testi: Çocukların aerobik güç düzeyleri 20 m mekik koşusu testi ile belirlendi. Aerobik gücün elde edilmesinde, 20 m Mekik Koşusu Testi sonuçlarına ilişkin Maksimal Oksijen Tüketimi $\left(\mathrm{VO}_{2} \mathrm{max}\right)$ 'nin tahmini tablosu kullanıldı (Ramsbottom ve ark., 1988; Reeves ve ark., 1999).

Tüm ölçümler Mehmet Akif Ersoy Üniversitesi (MAEÜ) Eğitim Fakültesi Spor Kompleksinde gerçekleştirildi.

\section{Verilerin Analizi}

Tüm parametrelere yönelik ortalama, standart sapma, maksimum ve minimum değerleri alındı. Çalışmaya katılan tüm çocukların sosyo-ekonomik yapıları ile fiziksel, fizyolojik ve teknik parametreleri arasındaki ilişkiler Korelasyon Analizi/ Pearson testi ile elde edildi.

\section{Bulgular}

Araştırma grubuna yönelik tüm bulgular aşağıdaki Tablo 1 ve Tablo 2' de ayrıntılı şekilde verildi. 
Güler D., (2019). Çocuklarda Sosyo-Ekonomik Düzeyin Fiziksel ve Fizyolojik Performanslarıyla İlişkisi. Gaziantep Üniversitesi Spor Bilimleri Dergisi, 4(3), 275-288.

Tablo 1: Araştırma Grubunun Fiziksel ve Fizyolojik Özellikleri

\begin{tabular}{|c|c|c|c|c|}
\hline Değişkenler & $\mathbf{n}$ & $\mathrm{X} \pm \mathrm{Sd}$ & Minimum & Maksimum \\
\hline Yaş (yıl) & 109 & $12,5 \pm 0,8$ & 11 & 14 \\
\hline Boy $(\mathrm{m})$ & 109 & $1,53 \pm 0,1$ & 1,32 & 1,74 \\
\hline Kilo (kg) & 109 & $45,6 \pm 9,7$ & 26 & 72 \\
\hline VKİ $\left(\mathrm{kg} / \mathrm{m}^{2}\right)$ & 109 & $19,2 \pm 2,8$ & 14,7 & 29,4 \\
\hline Vücut yağ yüzdesi (\%) & 109 & $18,0 \pm 6,6$ & 8,9 & 49,9 \\
\hline Endomorfi & 109 & $2,7 \pm 1,3$ & 1,1 & 7,6 \\
\hline Mezomorfi & 109 & $4,5 \pm 1,1$ & 1,7 & 8,1 \\
\hline Ektomorfi & 109 & $3,2 \pm 1,2$ & 0,1 & 5,8 \\
\hline Esneklik (cm) & 109 & $18,3 \pm 5,7$ & 7,5 & 33,2 \\
\hline Dikey sıçrama $(\mathrm{cm})$ & 109 & $38,1 \pm 7,7$ & 21,0 & 69,0 \\
\hline Mekik çekme (adet) & 109 & $38,1 \pm 8,2$ & 1,0 & 54,0 \\
\hline Barfikste kol çekme (adet) & 109 & $3,8 \pm 3,3$ & 0,0 & 16,0 \\
\hline 10 m sürat (sn) & 109 & $2,11 \pm 0,23$ & 1,43 & 2,90 \\
\hline 30 m sürat (sn) & 109 & $5,28 \pm 0,59$ & 4,19 & 6,91 \\
\hline Mekik koşusu (mekik sayısı) & 109 & $23,0 \pm 6,5$ & 9,0 & 42,0 \\
\hline $\begin{array}{lll}\begin{array}{l}\text { Aerobik } \\
(\mathrm{ml} / \mathrm{kg} / \mathrm{dk})\end{array} & \text { güç/max } & \mathrm{VO}_{2} \\
\end{array}$ & 109 & $34,7 \pm 4,9$ & 23,4 & 48,0 \\
\hline Anaerobikgüç (kgm/sn) & 109 & $62,1 \pm 15,2$ & 32,0 & 103,5 \\
\hline Teknik beceri (sn) & 109 & $25,96 \pm 2,20$ & 21,42 & 35,87 \\
\hline
\end{tabular}

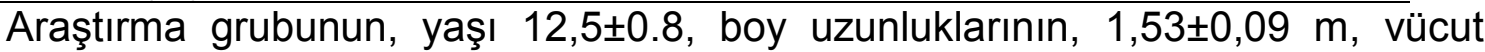

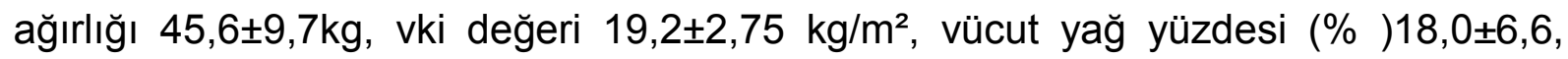

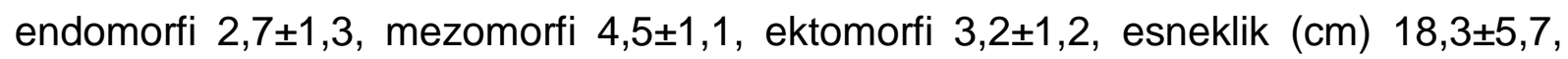

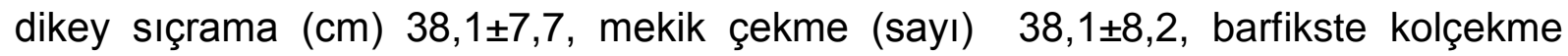

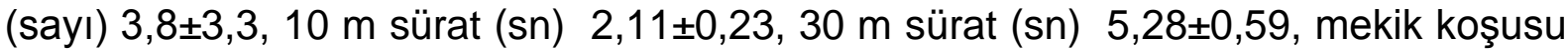
(mekik sayısı) 23,0 $\pm 6,5$, aerobik güç/maxvo $2(\mathrm{ml} / \mathrm{kg} / \mathrm{dk}) 34,7 \pm 4,9$, anaerobik güç

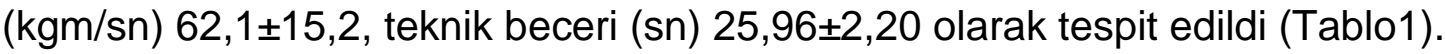

Tablo 2. Öğrencilerin Sosyo-Ekonomik Yapıları ile Performansları Arasındaki İlişki Dağılımı

\begin{tabular}{|c|c|c|c|c|c|c|}
\hline \multirow[t]{2}{*}{ Değişkenler } & \multirow[t]{2}{*}{$\mathbf{n}$} & $\begin{array}{c}\text { Anne } \\
\text { Eğitim }\end{array}$ & $\begin{array}{c}\text { Baba } \\
\text { Eğitim }\end{array}$ & $\begin{array}{l}\text { Aile } \\
\text { Geliri }\end{array}$ & $\begin{array}{l}\text { Yaşam } \\
\text { Çevresi }\end{array}$ & $\begin{array}{c}\text { Kardeş } \\
\text { Sayısı }\end{array}$ \\
\hline & & $r$ & $r$ & $r$ & $r$ & $r$ \\
\hline Boy (m) & 109 &, 172 & ,074 &,- 021 &,- 087 &, 024 \\
\hline Kilo (kg) & 109 &, 185 & ,193* &, 035 &,- 077 &, 086 \\
\hline VKI $\left(\mathrm{kg} / \mathrm{m}^{2}\right)$ & 109 &, 147 & ,230* &, 066 &,- 052 & ,088 \\
\hline Yağ Yüzdesi & 109 & ,163 & ,203* & ,035 & ,028 & ,001 \\
\hline Endomorfi & 109 & ,095 & ,162 & ,009 &,- 030 &,- 010 \\
\hline Mezamorfi & 109 & 070 & ,171 & ,115 & ,037 & ,147 \\
\hline Ektomorfi & 109 &,- 072 &,$- 204^{\star}$ &,- 088 & ,004 &,- 075 \\
\hline Esneklik (cm) & 109 &,- 006 & ,198* & ,073 &,- 153 &,- 004 \\
\hline Mekik çekme (sayı) & 109 & ,016 &, 135 &,- 003 & , 124 &, 162 \\
\hline Barfikste kol çekme (sayı) & 109 &, $310^{\star \star}$ & ,218* & ,026 &,- 145 &, 128 \\
\hline 10 m sürat (sn) & 109 &,- 109 &,- 125 &,- 060 & ,193* &, 045 \\
\hline 30 m sürat (sn) & 109 &,- 152 &,- 165 &,- 010 &, $303^{* *}$ &,- 084 \\
\hline Teknik beceri (sn) & 109 & ,025 & ,070 & ,013 &,- 151 &,- 076 \\
\hline Dikey Sıçrama (cm) & 109 & ,226* & ,200* & ,054 & ,001 & ,000 \\
\hline $\mathrm{VO}_{2} \max (\mathrm{ml} / \mathrm{kg} / \mathrm{dk})$ & 109 &, 073 & ,157 & ,149 &,- 097 & ,138 \\
\hline Anaerobik güç (kgm/sn) & 109 &, $271^{\star \star}$ &, $272^{\star \star}$ & ,063 &,- 065 & ,083 \\
\hline
\end{tabular}


Tablo 2' de, anne eğitimi ile dikey sıçrama $(p<0,01)$ ve barfikste kol çekme $(p<0,05)$ arasında; baba eğitimi ile kilo, esneklik, dikey sıçrama, barfikste kol çekme, VKİ ve yağ yüzdesi arasında $(p<0,05)$ pozitif anlamlı ilişki, baba eğitimi ile ektomorfi arasında anlamlı $(p<0,05)$ negatif ilişki bulundu. Anne ve baba eğitim düzeyi yükseldikçe anaerobik güç anlamlı $(p<0,01)$ olarak arttı. Öğrencilerin yaşadıkları çevre ile $10 \mathrm{~m}(\mathrm{p}<0,05)$ ve $30 \mathrm{~m}$ sürat $(p<0,01)$ 'leri arasında anlamlı pozitif ilişki belirlendi. Diğer değişkenler ile performans parametreleri arasında anlamlı $(p<0,01$, $\mathrm{p}<0,05)$ bir ilişki bulunmadı.

\section{Tartışma ve Sonuç}

Son yıllarda gelişimini tamamlamış ülkelerde çocukların büyüme ve gelişmelerine ilişkin sosyo-ekonomik farklılıklar bulunmazken, gelişememiş ve gelişme sürecinde olan ülkelerde bu farklar hala devam etmektedir. Sağlıklı ve güçlü nesillerin tesisinde ve yüksek performansa sahip insan gücüne erişilmesinde çocukların bir kısım olumsuz etkenlerden mümkün olduğunca uzak yetiştirilmeleri önemli görülmektedir. Buna ilişkin olarak çocuklarda sosyo-ekonomik farklılıkların düzeylerini belirleme ve farklılıklara yönelik önlemleri alma konusundaki araştırmalar son yıllarda dikkate değer şekilde çoğalmıştır (Erden ve Oğuz, 2009). Ayrıca, sporcuların performanslarına etki eden sosyo-ekonomik durumun önemli parametre olarak ortaya çıkması anlamlı kabul edilmektedir. Sporun toplumda yaygınlaştırılması ve belirli sporlar (futbol, voleybol, hentbol, basketbol gibi) dışında da çocuklara maddi kaynaklar oluşturulması, onlara elit düzey sporcular model gösterilerek sporun tanıtılması gerekmektedir.

Farklı sosyo-ekonomik seviyelerdeki çocukların fiziksel-fizyolojik gelişimleri ile ilgili yapılan bir araştırmada sosyo-ekonomik seviye artınca çocukların boy uzunluklarının da tutarlı şekilde arttığı ve çocukların vücut ağırlığı ile boy uzunluklarının anne-babalarının eğitimi, ailelerinin geliri ve sosyo-ekonomik düzeyi belirleyen diğer bileşenlere göre farklılıklar saptandığı bildirilmiştir (Temel ve ark., 1999). Büyüme sürecinin fizyolojik olgunlaşma ve genetik yatkınlıklara ek olarak beslenme, düzenli yaşam ve sosyo-ekonomik düzey gibi çevresel parametrelerin de etkisinde olduğu; beslenme, düzenli yaşam ve sosyo-ekonomik düzey etkenlerinin çocuk, genç ve yetişkinlerin fitnes ve sportif verim düzeylerine etki gösterdiği bildirilmektedir. Dolayısıyla, çocukların büyüme ve olgunlaşmalarında ailelerin sosyo- 
Güler D., (2019). Çocuklarda Sosyo-Ekonomik Düzeyin Fiziksel ve Fizyolojik Performanslarıyla İlişkisi. Gaziantep Üniversitesi Spor Bilimleri Dergisi, 4(3), 275-288.

ekonomik düzeylerinin etkili parametre olduğu belirtilmektedir (Berning et al. 1983; Goslin and Burden 1986; Malina and Bouchard 1991). Bizim araştırmamızda tam tersi olarak, anne eğitim düzeyi ile boy ve kilo arasında ve baba eğitim düzeyi ile boy arasında, gelir düzeyi ve diğer sosyo-ekonomik faktörler arasında anlamlı bir ilişki $(p>0,05)$ bulunmazken, yalnızca baba eğitimi ile kilo arasında anlamlı $(p<0,05)$ pozitif ilişki bulunmuştur (Tablo 2). Bunun nedeni de, Temel ve ark. (1999)'nın çalışmaları ile bu çalışma arasındaki zaman farkı olabilir. Çünkü 1999 yıllarında yaşayan aileler ile 2015 yılından sonra yaşayan ailelerin hem beslenme düzeyleri hem de sosyoekonomik yapıları arasında farklılık bulunabilir.

Güler ve ark. (2004), çocuklarda sosyo-ekonomik düzeyin fiziksel uygunluğa etkisini araştırdıkları araştırmada, anne eğitimi ve baba eğitimi ile esneklik arasında negatif yönde anlamlı ( $p<0,001)$ ilişki bulmuşlardır. Araştırmamızda ise anne eğitimi ile esneklik arasında anlamlı ilişki görülmezken, baba eğitimi ile esneklik arasında pozitif anlamlı $(p<0,05)$ ilişki görülmüştür (Tablo 2). Kız çocuklarında sosyo-ekonomik düzeyin fiziksel uygunluğa etkisinin araştırıldığı bir başka araştırmada ise sporla uğraşmayan öğrencilerin skinfold toplamları ile anne ve baba eğitim düzeyi arasında anlamlı ilişki görülmemiştir (Güler ve ark., 2004). Bu araştırmada ise sporla uğraşan öğrencilerin anne eğitim durumları ile yağ yüzdeleri ve VKİ ortalamaları arasında anlamlı ilişki $(P>0,05)$ bulunmazken, baba eğitim durumu ile yağ yüzdesi ve VKi ortalamaları arasında anlamlı $(P<0,05)$ pozitif ilişki görülmüştür. Yaptığımız çalışma sonuçları ile literatür karşılaştırıldığında anne eğitimi ve baba eğitimi ile esneklik performansı ve baba eğitimi ile yağ düzeyi açısından literatüre paralel görülmemektedir.

Erkek maratoncuların sosyal çevreleri ve ekonomik durumlarının spora yönlenmelerine etkisi ile ilgili bir çalışmada, araştırma grubunun gelir seviyesi ile uluslararası yarışmalarda elde ettikleri performans arasında anlamlı $(p<0,05)$ pozitif ilişki bulunurken (Akandere ve ark., 2009); çocuklarda fiziksel aktivite ile sosyoekonomik düzey arasındaki ilişkilere yönelik bir çalışmada da, anne ve babanın eğitimi ve gelir düzeyleri ile fiziksel performansları arasında $(P>0,05)$ anlamlı ilişki bulunamamıştır. Aynı çalışmada asgari ücret ve orta düzeyde gelir grubuna ilişkin parametreler incelendiğinde yağ düzeyi, bazal metabolik hız ve fiziksel aktivite düzeyi arasında anlamlı $(P<0,01, p<0.05)$ farklar olduğu sonucuna varılmıştır (Çekiç ve ark., 2010). Bir başka çalışmada ise, ekonomik düzeyi yüksek olan çocukların motorik 
Güler D., (2019). Çocuklarda Sosyo-Ekonomik Düzeyin Fiziksel ve Fizyolojik Performanslarıyla İlişkisi. Gaziantep Üniversitesi Spor Bilimleri Dergisi, 4(3), 275-288.

testlerde yüksek performans gösterdikleri bildirilmiştir (Krobhholz 1997). Yaptığımız araştırmada ise aile gelir düzeyi ile performans parametreleri arasında anlamlı $(P>0,01, P>0,05)$ ilişki bulunmamıştır (Tablo 2). Dolayısıyla, yaptığımız çalışma sonuçları gelir düzeyi ile performans kriterleri ilişkisi açısından literatüre koşut seyretmemektedir.

Stephens ve Caspersen (1994) fiziksel aktivite, fitnes ve sağlık demografisi isimli eserlerinde, eğitim düzeyi yüksek olanların fiziksel aktivite düzeylerinin de yükseldiğini bildirmişlerdir. Albayrak (1998), bireylerin fiziksel aktivitelerine yönelik yaptığı çalışmasında, aile geliri düzeyi ve fiziksel aktivite sıklığı arasında anlamlı fark bulamamış, fakat aile geliri yüksek olanların fiziksel aktivite frekanslarının daha yüksek bulunduğunu bildirmiştir. Top ve Yıldız (2017) da 11-14 yaş grubu çocuklarda deografik özellikler, motor verim düzeyleri ile yaşam kaliteleri arasındaki ilişkileri inceledikleri çalışmalarında, motor gelişim düzeyleri ile yaşam kalitesi arasında pozitif ilişki olduğunu belirlemişler, bunu çeşitli sosyo-ekonomik farklılıkların etkilediğini bildirmişlerdir. Koçak ve ark. (2002), ise çocuklarda anne-baba eğitim düzeyi ve fiziksel aktivite düzeylerine yönelik çalışmalarında, 11-14 yaş çocuklarda anne-baba eğitim düzeyi ile çocukların fiziksel aktivite düzeyleri arasında negatif ilişki olduğu sonucuna varmışlar; devlet ve özel okullarda okuyan çocukların fiziksel uygunluklarının araştırıldığı bir başka çalışmada da, yüksek sosyo-ekonomik seviyedeki çocukların fiziksel aktivite düzeylerinin düşük olanlardan daha yüksek olduğu gözlenmiştir (Tekelioğlu, 1999). Güney Avustralya' da kırsal ve merkez bölgelerde yaşayan çocuklar üzerinde yapılan bir araştırmada, sosyo-ekonomik faktörler ve çevresel faktörler fiziksel uygunluk değerleri ile yakından ilişkili görülmüştür (Dolman et al 2002). Güney Afrika'daki çocuklarda sosyo-ekonomik düzey ile fiziksel aktivite ve vücut kompozisyonu arasındaki ilişkilerle birlikte fiziksel aktivite frekansları üzerinde anne etkisi, televizyon seyretme, aktivite düzeyi ve vücut kompozisyonu ilişkileri incelenmiş; sosyo-ekonomik statüsü yüksek çocukların düşük olanlara göre daha fazla spora katıldıkları, daha yüksek fiziksel uygunluğa sahip oldukları, eğitim düzeyi yüksek annelere sahip oldukları, az televizyon izledikleri belirlenmiştir (McVeigh ve ark., 2004). Fiziksel aktivite yapan çocuklara yönelik başka bir çalışmada, modern ülkelerdeki sosyo-ekonomik düzeyi düşük aileler ve çocuklarında obezite sık görülürken, gelişme sürecinde olan ülkelerde ekonomik düzeyi yüksek olan aileler ve çocuklarında daha fazla bulunmuştur (Goran ve ark., 
Güler D., (2019). Çocuklarda Sosyo-Ekonomik Düzeyin Fiziksel ve Fizyolojik Performanslarıyla İlişkisi. Gaziantep Üniversitesi Spor Bilimleri Dergisi, 4(3), 275-288.

1998). Sporcu ve sporcu olmayan ergenlerde demografik profillerin incelendiği bir başka araştırmada, sporcu ergenler ile sporcu olmayan ergenler arasında anne ve baba eğitimi, mesleği ve aile gelirleri açısından anlamlı farklılıklar $(p<0.05)$ gözlenmiş, sporcu bireylerin anne ve baba eğitim düzeyleri ile aile gelirleri sporcu olmayanlardan daha yüksek bulunmuştur (Dorak ve Özşaker, 2011). Yan (2007) da 10-13 yaş arası çocuklarda yaptığı araştırmasında, sosyo-ekonomik farklılıkları olanların fiziksel ve fizyolojik özelliklerini karşılaştırmış, asgari ücretli ve orta gelir düzeyinde olanların günlük enerji tüketimi ve yağ oranlarının gelir düzeyi yüksek olanlardan daha iyi olduğunu tespit etmiştir. Yukarıdaki çalışmalarla bu çalışma karşılaştırıldığında Stephens ve Caspersen (1994), McVeigh ve ark., (2004), Dorak ve Özşaker (2011) ve Albayrak (1998)' ın çalışmaları ile fiziksel aktiviteye katılım; Yan (2007)'ın çalışması ile yağ oranları; McVeigh et al (2004), Dorak ve Özşaker (2011), Top ve Yıldız (2017)' ın çalışmaları ile ise anne-baba eğitiminin çocukların sportif performanslarına olan pozitif etkileri bakımından benzer sonuçlar elde edilmiştir.

Buenos Aires/Arjantin'de çocukların fiziksel uygunlukları üzerinde sosyoekonomik bileşenlerin etkilerinin değerlendirildiği bir çalışmada, şehirleşme imkanları arttıkça çocukların fiziksel yapı ve performanslarında anlamlı farklar tespit edilmiş; bu anlamlı farkların erkeklerin antropometrik ve motorik testlerinde, kızların yalnızca motorik testlerinde görüldüğü belirtilmiştir. Bunların yanında, sosyo-ekonomik parametrelerin çocukların fiziksel uygunluğunu yüksek oranda etkilediği ve sosyoekonomik düzeyi yüksek olanların sportif faaliyetlere katılım oranlarının daha fazla bulunduğu sonucuna varılmıştır (Perez, 1991). Bu çalışmada ise çocukların yaşam çevreleri iyileştikçe $10 \mathrm{~m}(\mathrm{p}<0,05)$ ve $30 \mathrm{~m}$ sürat $(p<0,01)$ özellikleri de anlamlı şekilde yükselmekte, ancak, diğer parametrelerle sosyo-ekonomik faktörler arasında anlamlı bir ilişki görülmemektedir. Farklı sosyo-ekonomik düzeydeki çocukların fiziksel performanslarının araştırıldığı bir başka çalışmada, alt sosyo-ekonomik düzeydeki çocukların hareketlilik, kol kuvveti ve dayanıklılık koşularında daha başarılı, üst düzeydekilerin ise çabukluk, bacak kuvveti, anaerobik güç becerilerinde daha başarılı oldukları belirtilmiştir. Aynı çalışmada, alt sosyo-ekonomik düzey çocukların hareketlilik, kol kuvveti ve dayanıklılık performanslarında yüksek düzey sosyo-ekonomik gruba göre daha başarılı olmalarının bir nedeninin, düşük sosyoekonomik düzeydeki çocukların zorlu çevre şartlarında yaşamalarının 
Güler D., (2019). Çocuklarda Sosyo-Ekonomik Düzeyin Fiziksel ve Fizyolojik Performanslarıyla İlişkisi. Gaziantep Üniversitesi Spor Bilimleri Dergisi, 4(3), 275-288.

gösterilebileceği; yüksek düzey sosyo-ekonomik gruptaki çocukların başarısızlıklarının ise okul dışı hareket ve aktivite imkanlarının aileleri tarafından sınırlandırılması ve yüksek gelir düzeyine bağlı dengesiz beslenme alışkanlığının gösterilebileceği bildirilmiştir. Özellikle kol kuvveti performansında, yüksek sosyoekonomik düzeydeki çocukların fazla kiloya sahip olmalarından ötürü, bu testte başarısız oldukları düşünülmekte; bununla birlikte çabukluk, mekik koşusu, bacak kuvveti gibi patlayıcı kuvvet ve reaksiyon süratine dayalı performansta yüksek sosyoekonomik düzeydeki çocukların başarılı olma nedenlerinin de okuldaki sportif faaliyet ve sosyal imkanların yeterince iyi bulunması, sağlıklı ve dengeli beslenmeleri ve iyi eğitim imkanlarından kaynaklandığı bildirilmektedir (Erden ve Oğuz, 2009). Bu çalışmada, çocukların anne ve babalarının eğitim düzeyleri yükseldikçe hareketlilik, kol kuvveti ve anaerobik güç performanslarında daha başarılı olmaları, hareketlilik ve kol kuvveti açısından Erden ve Oğuz (2009)' un çalışmasına koşut seyrederken, anaerobik güç performansları yönünden seyretmemektedir. Bunun da, bu çalışmadaki çocukların sporcu olmaları ve sürekli aktif olan çocuklarda bazı sosyoekonomik bileşenlerinin etkisinin azalmasından kaynaklı olabileceği düşünülmektedir. Sporda performans faktörlerinin araştırıldığı bir başka çalışmada ise, bilimsel kriterler çerçevesinde etkin motivasyonel iç-dış uyaranların ekonomik yetkinlik, yeterli dinlenme, dengeli beslenme, boş zamanların doğru ve etkin değerlendirilmesi, uygun ev koşulları, olumlu alışkanlıkların sportif performansı ve sporda başarıyı maksimal düzeye çıkarabileceği vurgulanmıştır (Bayraktar ve Kurtoğlu, 2009). Sporda etkin performans artışının oluşmasında ekonomik yeterlilik, yeterli beslenme, olumlu alışkanlıkların oluşması ve uygun ev koşulları gibi etkenlerin katkısı bizim çalışmamızla paralellik göstermekte ve sporla uğraşan çocukların sosyo-ekonomik düzeylerinin performanslarında belirgin artışa sebep teşkil ettiği ve sürekli aktif yaşamın çocuklarda bazı sosyo-ekonomik bileşenlerin etkisini ortadan kaldırdığı görülebilmektedir.

Değerlendirmeler ışığında, periyodik olarak aktif çocuklarda, anne-baba eğitiminin kol ve bacak kuvveti, hareketlilik ve anaerobik güce; yaşadıkları çevrenin ve ev ortamının yağ düzeylerine olumlu, esnekliğe de olumsuz etkili olduğu, ancak, periyodik olarak fiziksel aktiviteye katılan çocuklarda, sosyo-ekonomik düzeyin etkilerinin ortadan kalktığı görülmektedir. Sonuç olarak, sosyo ekonomik düzeyin, 
Güler D., (2019). Çocuklarda Sosyo-Ekonomik Düzeyin Fiziksel ve Fizyolojik Performanslarıyla İlişkisi. Gaziantep Üniversitesi Spor Bilimleri Dergisi, 4(3), 275-288.

özellikle de, anne-baba eğitimi ve yaşam çevresinin çocuklarda yağ düzeyi, kuvvet, anaerobik güç ve esneklik (hareketlilik) performansını etkileyebileceği söylenebilir.

\section{Kaynaklar}

Akandere, M., Baştuğ, G., Akdoğan, Z. (2009). Erkek Maratoncularda Sosyal Çevre ve Ekonomik Durumun Spora Yönelmeye Etkisi. Selçuk Üniversitesi Sosyal Bilimler Enstitüsü Dergisi, 22, 459-466.

Akgün, HS. (1997). Sosyo-Ekonomik Yönden Farklı İki İlkokul Öğrencilerinin Fizik Büyüme Durumları ve Etkileyen Bazı Faktörlerin Araştırılması. Yüksek Lisans Tezi, H.Ü. Sağlık Bilimleri Enstitüsü, Ankara

Albayrak, MY. (1998). 14-35 Yaş Arasındaki Bireylerin Fiziksel Aktivite Düzeyi.

Yüksek Lisans Tezi, M.Ü. Sağlık Bilimleri Enstitüsü, İstanbul

Astrand, PO., Rodahl, K. (1986). Textbook of Work Physiology, New York: McGraw Hill, 237-273.

Bayraktar, B., Kurtoğlu, M. (2011) Dopingle Mücadele Ve Futbolda Performans Artırma Yöntemleri. Ed: T. Atasü, İ. Yücesir, B. Bayraktar, Ankara: Ajansmat Matbaacılık, 301-328.

Bayraktar, B., Kurtoğlu, M. (2009). Sporda Performans Etkili Faktörler, Değerlendirilmesi ve Artırılması. Klinik Gelişim Dergisi, 22 (1), 16-24.

Bayraktar, G. (2011). Bayan Güreşçilerin Güreş Sporunu Algılamalarına Yönelik Tutumlarının Sosyo-Ekonomik ve Sosyo-Kültürel Değişkenlere Göre İncelenmesi. Selçuk Üniversitesi Beden Eğitimi ve Spor Bilim Dergisi, 13 (1), 39-43.

Bernink, MJE., Erich, WBM., Peltenburg, AL., Zonderland, ML., Huısveld, IA. (1983). Height, Body Composition, Biological Maturation and Training in Relation to Socio-Economic Status in Girls Gymnasts, Swimmers and Controls. Growth, $47,1-12$.

Carter, JEL., Heath, BH. ( 1990). Somatotypeing-Development and Applications. Camrıdge University Press, Cambridge.

Çekiç, S., Özbar, N., Küçük Yetgin, M. (2010). İlköğretim Öğrencilerinde (11-12 Yaş Grubu) Fiziksel Aktivite Düzeyinin Sosyo Ekonomik Düzey İle İlişkilendirilmesi. 11th International Sports Sciences Congress, 10 to 12 October 2010, Antalya. 
Dollman, J., Norton, K., Tucker, G. (2002). Anthropometry, Fitness and Physical Activity of Urban and Rural South Australian Children. Pediatric Exercise Science, 14: 297-312.

Dorak, F. Özşaker, M. (2011). Spor Yapan ve Spor Yapmayan Ergenlerin SosyoDemografik Profilleri. Spor Hekimliği Dergisi, 46, 29-36.

Erden, S., Oğuz, H. (2009). Bursa İlinde Farklı Sosyo-Ekonomik Düzeye Sahip Aile Çocuklarının Fiziksel Performans Özelliklerinin İncelenmesi. U.Ü. Eğitim Fakültesi Dergisi 22 (1), 279-292.

Goran MI., Gower BA., Nagy TR., Johnson RK. (1998). Developmental changes im energy expenditure and physical activity in children: evidence for a decline in physical activity in girls before puberty. Pediatrics,101(1): 887- 891.

Goslın, BR., Burden, SB. (1986). Physical Fitness of South African School Children. J. Sports Med., 26, 128-136.

Güler, D., Balcı, ŞS., Çolakoğlu, F., Karacan, S. (2004). The Evaluatıon of The Impact of Socıo-Economıc Level Over The Health-Related Physıcal FItness of Gırls. 17-20 November 2004 10. ICHPER-SD Europe Congress \& 8th International Sports Science Congress, Antalya/TURKEY, Abstract Book, 66.

Güler, D., Günay, M. (2004). Çocuklarda Sosyo-Ekonomik Düzeyin Fiziksel Uygunluğa Etkisinin AAHPERD Fiziksel Uygunluk Test Bataryası İle Değerlendirilmesi. GÜ Kırşehir Eğitim Fakültesi Dergisi, 5 (1), 11-23.

IOC (International Olympic Committee). (1996). The Child And Adolescent Athlete. Edt: Oded Bar-Or, Blackwell Science Ltd., London.

Koçak, MS., Harris, MB., Kin İşler, A., Çiçek, Ş. (2002). Physical Activity Level, Sport Participation and Parental Education Level in Turkish Junior School Students. Pediatr. Exerc. Sci., 14, 147-154.

Krobhholz, H. (1997). Physical Performance in Relation to Age, Sex, Social Class and Sport Activities in Kindergarten and Elementary School. Perceptual and Motor Skills, 84, 1168-1170.

Kuru, E., Pepe, K. (2002). Beden Eğitimi ve Spor Öğretmenliği Özel Yetenek Sınavlarına Katılan Öğrencilerin Sosyoekonomik Profilleri. Gazi Üniversitesi Gazi Eğitim Fakültesi Dergisi, 22 (1), 253-265.

Macdougall, JD., Wenger, HA., Green, HJ. (1983). Physiological Testing of The Elite Athlete. Mouvement Publication Inc. 
Malına, RM., Bouchard, C. (1991). Growth, Maturation and Physical Activity, Human Kinetics Books, 391-414.

Mcveigh, JA. Norris, SA. De Wet, T. (2004). The relationship between socioeconomic status and physical activity patterns in South African Children. Acta Paediatr, 93, 982-988.

Özkara, A. (2004). Futbolda Testler ve Özel Çalışmalar. Kuşçu Etiket ve Matbaacılık, Ankara.

Perez, GEN. D'angelo, CP. Zabala, RD. (1991). Physical Fitness in Children an Adolescents from Differing Socioecomomic Strata, In Shephard Roy J; Parizkova, J. (Eds) Human Growth, Physical Fitness and Nutrition. Med. Sport Sci. Basel Karger, 31, 80-98.

Ramsbottom, R., Brewer, J., WilliamS, C. (1988). Progressive Shuttle Run test to Estimate Maximal Oxygen Uptake. Brit. J. Sports Med., December (22) 4, 141-144.

Reeves, SL., Poh, BK., Brown, M., Tizzard, NH., Ismail, MN. (1999). Anthropometric Measurements and Body Composition of English and Malaysian Footballers. Mal. J. Nutr. 5, ,79-86.

Short FX., Winnick JP. (2005). Test İtems and Standards Related to Body Composition on The Brockport Physical Fitness Test. Adapt Phys Activ Q (APAQ), 22 (4), 356-370.

Stephens,T., Caspersen,CJ. (1994), The Demograpy of Physical Activity, Fitness and Health, International Proceedings and Consensus Statement. Human Kinetics, Illinois.

Tekelioğlu, A. (1999). Devlet Okulu ve Özel Okulda Okuyan 11-13 Yaş Grubu Kız ve Erkek Çocukların Fiziksel Uygunlukları. Doktora Tezi, G.Ü. Sağlık Bilimleri Ensitüsü Beden Eğitimi ve Spor ABD, Ankara.

Temel, F., Avcı, N., Ersoy, Ö., Turla, A. (1999). Farklı Sosyo-Ekonomik Düzeylerdeki 0-6 Yaş Çocukların Fiziksel Gelişimlerinin İncelenmesi. Gazi Beden Eğitimi ve Spor Bilimleri Dergisi, 4 (3), 43-50.

Top, E., Yıldız, M. (2017). 11-14 Yaş Grubu Çocukların Sosyo-Demografik Özellikleri, Motor Performans Düzeyleriyle Yaşam Kaliteleri Arasındaki İlişkinin İncelenmesi. Atatürk Üniversitesi Beden Eğitimi ve Spor Bilimleri Dergisi, 19 (1), 41-56. 
Güler D., (2019). Çocuklarda Sosyo-Ekonomik Düzeyin Fiziksel ve Fizyolojik Performanslarıyla İlişkisi. Gaziantep Üniversitesi Spor Bilimleri Dergisi, 4(3), 275-288.

Yan, Y. (2007).10-13 Yaş Çocuklarda, Sosyo-Ekonomik Yapının Fiziksel Aktivite ve Fiziksel Uygunluk Düzeyine Etkisi. Yüksek Lisans Tezi, M.Ü. Sağlık Bilimleri Enstitüsü, İstanbul. 